\title{
THE LABOR SUPPLY AND TAX REVENUE CONSEQUENCES OF FEDERAL SAME-SEX MARRIAGE LEGALIZATION
}

\author{
Adam Stevenson
}

This paper estimates the effects of same-sex marriage legalization on federal income tax revenue using changes in taxation generated from the 2003 Jobs and Growth Tax Relief Reconciliation Act. These estimates rely critically on the responsiveness of labor supply and marital choice to changes in the tax code. In addition, this paper proposes a novel measure of the marriage penalty that incorporates the fact that individuals will respond optimally to changes in marginal tax rates within the household. The estimates suggest that legalization will result in a small gain, around $\$ 34$ million per year, in federal income tax revenue.

Keywords: labor supply, marriage penalty, sexual orientation, DOMA

JEL Codes: D10, H24, J12

\section{INTRODUCTION}

- he debate over whether same-sex couples should be granted the legal right to marry has become a hot-button issue in the United States in the last decade. The Defense of Marriage Act (DOMA) prohibits the recognition of same-sex marriage at the federal level, but a growing number of states and major cities have granted the right to either marry or enter into other officially-recognized relationships. President Obama recently ordered the Justice Department to cease defense of DOMA (Savage, 2011). Both the federal and a number of state governments have explicitly justified their same-sex marriage bans on the basis of adverse tax revenue and expenditure effects (Hawkins, 2009). This paper explores the effects of same-sex marriage legalization on federal income tax revenue.

Same-sex marriage legalization has the direct impact of allowing a change in a household's legal tax filing status, which can change the household's income tax burden, via the "marriage penalty" (which may be a positive tax, or a negative subsidy). This change in the tax schedule presumably causes a change in labor supply, which also affects income tax revenue. Further, the desire to capture a marriage subsidy or avoid

Adam Stevenson: Department of Economics, University of Michigan, Ann Arbor, MI, USA (adamstev@ umich.edu) 
a marriage tax may cause marriage rates to vary along with the marriage penalty. To understand the effect of same-sex marriage legalization on income tax collection, we must understand the causal effect of these penalties on the likelihood of marriage, and how this change in taxation influences labor supply choices.

The sensitivity of labor supply to taxation suggests that labor supply and taxable income may change upon marriage. A novel measure of the marriage penalty, called the endogenous marriage penalty, is introduced to capture this effect. ${ }^{1}$ This endogenous marriage penalty contrasts with the standard measure, which assumes no labor market response to marriage and divorce. As such, it may be interpreted as an "instantaneous" measure. These measures of the marriage penalty do not differ substantially for heterosexual couples, but important differences arise among homosexual households.

In terms of measuring the tax revenue consequences of legalizing same-sex marriage, the paper that comes closest to this one is Alm, Badgett, and Whittington (2000), which applies various assumptions about gay and lesbian household composition to tabulate a range of potential aggregate outcomes. The most systematic investigation of the net budgetary effects of same-sex marriage legalization is from the CBO (2004), which draws heavily on Alm, Badgett, and Whittington (2000). CBO estimates an $\$ 800$ million to $\$ 1$ billion annual budget windfall from legalization, $\$ 200$ million to $\$ 400$ million of which come from income tax revenues. I estimate that same-sex marriage legalization would increase federal income tax revenues somewhere between \$20 million and $\$ 40$ million. This reduces the CBO's estimates of net budgetary gains by almost half. That said, the net federal budgetary effects remain positive under any reasonable set of economic assumptions. Under the most pessimistic set of assumptions presented, tax revenues would fall $\$ 81$ million upon legalization, leaving a net gain to the federal government budget on the order of $\$ 300$ million.

The Jobs and Growth Tax Relief Reconciliation Act (JGTRRA) of 2003, an acceleration of the 2001 Economic Growth and Tax Relief Reconciliation Act (EGTRRA) (together frequently called the "Bush tax cuts") provides a useful natural experiment. ${ }^{2}$ The Bush tax cuts implemented a number of reforms, but two primary changes were a general tax cut and a decrease in the average marriage penalty. The JGTRRA in particular served as an exogenous tax shock. The EGTRRA scheduled a slow phase-in of marriage penalty reforms and tax bracket adjustments, but the JGTRRA abruptly implemented all the planned income tax changes starting in tax year 2003. These cuts, the most substantial tax reforms in the U.S. of the last 15 years, have not been exploited as a source of variation in the question of household structure, and have only occasionally been used in studies of labor supply choice (Heim, 2009; Auten, Carroll, and Gee, 2008). Similarly, while a small number of papers have studied the labor supply of same-sex couples, few have based their estimates on plausibly exogenous shocks to net wages.

\footnotetext{
1 Sjoquist and Walker (1995) have estimated marriage penalties at the aggregate level assuming that labor market choices differ between married and non-married cohabiting couples (finding little evidence of aggregate changes), but I am not aware of any paper that estimates the behavioral response from microdata.

2 Keifer et al. (2002) provides a detailed description of the EGTRRA.
} 


\section{DATA AND DESCRIPTIVE STATISTICS}

The main source of data for this study is the American Community Survey (ACS) for years 2003-2004. Some tax and demographic statistics are taken from 2000 through 2007 to include four years of data before and after the implementation of the JGTRRA while excluding the influence of other tax reforms (in particular the substantial Economic Stimulus Act of 2008). Following the literature on familial labor supply at prime working age, all households where either member is older than age 60 , or is too young to participate in the labor market, are dropped (Devereaux, 2004). A 2 percent random sample of heterosexual households from the ACS is used so that the samples of heterosexual and homosexual couples are of comparable size in most years.

Since the Census Bureau does not ask any questions about sexual behavior or identity, the only way to identify homosexuals is through cohabitation and reported relationship status. There are well-documented problems with the Census coding of same-sex partners (Black et al., 2007), creating a large number of "false positive" homosexual couples among households with allocated marital status. As suggested by Black, et al. (2007), households with allocated marital status are omitted. A number of true same-sex couples who identify as married will also have allocated marital status and will be dropped in this process. BGST estimate that 10 percent of the women dropped this way are homosexual, and 17 percent of the men. In the remaining sample, 0.66 percent of households are same-sex.

A worker's marginal wage is $w(1-\mu)$, where $\mu$ represents the federal marginal income tax rate, including the employee's share of the payroll (FICA) tax. Tax data come from the NBER's TAXSIM program (Feenberg and Coutts, 1993), estimated using all applicable data available in the ACS. ${ }^{3}$ The gross wage $w$ is calculated by taking annual wage, salary, and self-employment earnings and dividing by annual hours worked (calculated from typical weekly hours worked times weeks worked in the year). Individuals with "extreme" implied wage rates, below $\$ 2$ and above $\$ 200$, as measured in 2004 real dollars are dropped (following Blau and Kahn, 2007). Primary earners overwhelmingly participate in the market, and the few households where the primary earner has zero reported hours are also dropped.

Table 1 describes the characteristics of household members within the sample. When studying household income and specialization, it is important to differentiate between primary and secondary earners (Antecol and Steinberger, forthcoming). Most theoretical and empirical approaches treat the male as the primary earner in heterosexual households. The primary earner in homosexual households is the member whose annual income is greater.

Consistent with Black, Sanders, and Taylor (2007), individuals in homosexual households have substantially fewer children than those in heterosexual households. Interestingly, homosexual households are more specialized (along the dimension of market versus non-market human capital) than are heterosexual husbands and wives.

\footnotetext{
3 Potentially important variables not found in the Census questionnaires include capital gains income and expenditures on child care, health care, mortgage interest, and charitable donations.
} 


\begin{tabular}{|c|c|c|c|c|c|c|c|c|c|}
\hline 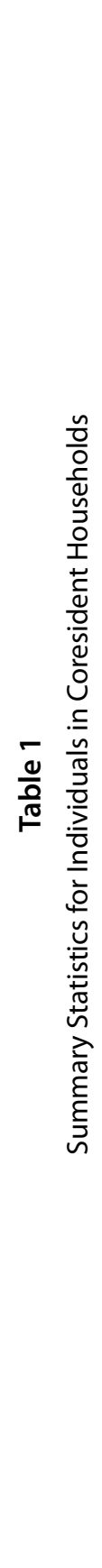 & 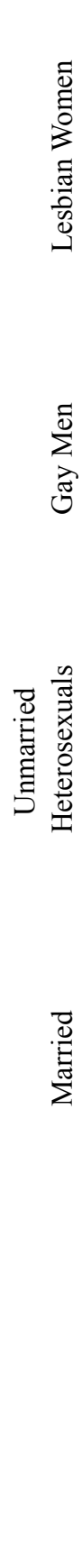 & 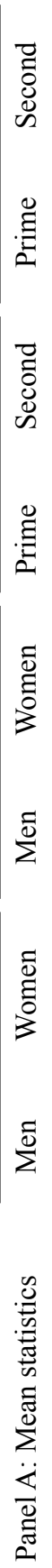 & 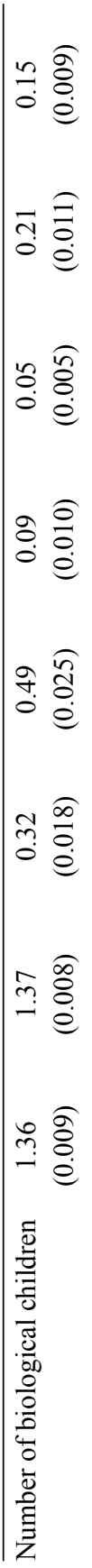 & 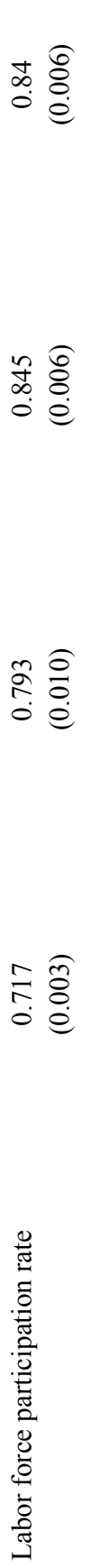 & 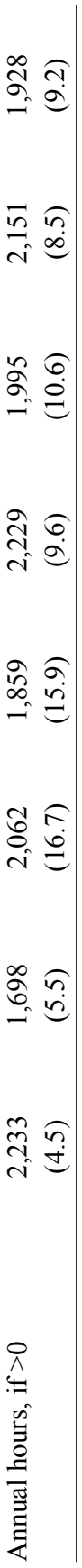 & 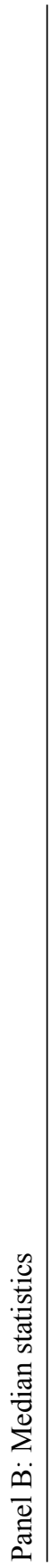 & 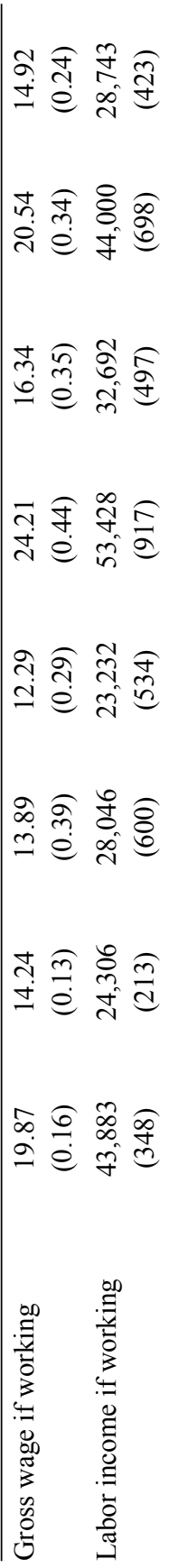 & 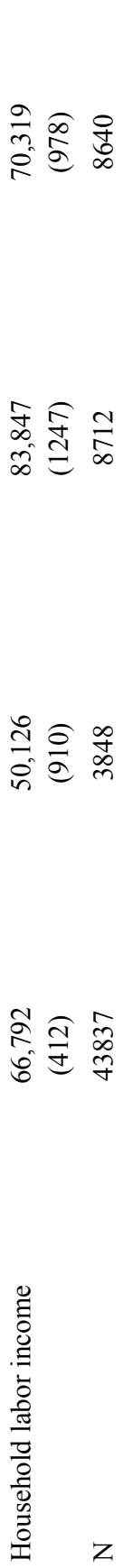 & 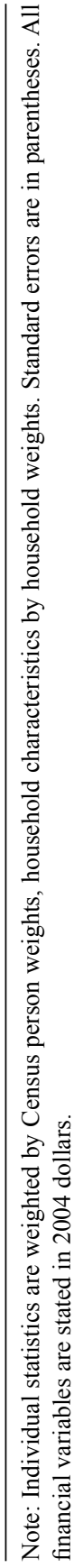 \\
\hline
\end{tabular}


Married men and women have identical average levels of education, and among those who work, married women earn about 72 percent of their spouse's wages. Gay secondary earners have 0.7 fewer years of education and median wages that are 67 percent of the primary earners'. The household wage gap is smaller in lesbian households than in gay households, but greater than in married households.

\section{MARRIAGE AND TAXES}

To measure the marriage penalty, we must know the tax liabilities in the observed and counterfactual marital situations. In principle, it is simple to define actual and counterfactual taxes. For any pair of individuals (following the notation of Berliant and Rothstein (2003)), define each individual's income tax liability when single as $T_{s}\left(y_{e}\right)$ where $y_{e}$ indicates the vector of taxable income streams for earner $e \in\{1,2\} . T_{s}(\cdot)$ is a function representing the federal tax schedule for unmarried persons in year $t$. If two individuals marry, the tax liability is $T_{m}\left(y_{1}, y_{2}\right)$, where $\left.T_{m}(\cdot),\right)$ is a function representing the federal tax schedule for married couples. The marriage penalty $P$ is the increase in taxes when a household of two single individuals instantaneously enter into the state of marriage,

$$
P\left(y_{1}, y_{2}\right) \equiv T_{m}\left(y_{1}, y_{2}\right)-\left(T_{s}\left(y_{1}\right)+T_{s}\left(y_{2}\right)\right) .
$$

Clearly, when $P_{t}\left(y_{1}, y_{2}\right)<0$, there is a negative marriage penalty, or a marriage subsidy. Typically, all variables (and most importantly, labor market income) are held fixed to calculate the penalty. Under this assumption, the measured penalty is best interpreted as an instantaneous change in tax burden among the partners, before any economic responses to the change in marital status can occur.

Calculating $T_{m}\left(y_{1}, y_{2}\right)$ is simple, since the federal tax schedule pools household non-labor income and children. Taxes if single are calculated under the assumption of a "divorce" and a split of assets, implying that unmarried couples (whether actually, or counterfactually divorced) equally split all non-work income between the two members. The standard tax-minimization algorithm assigns all child deductions to the higher earner. This is an unappealing assumption among same-sex couples where there simply cannot be shared biological children. Parents always claim a child who is theirs and who is not the biological child of their partner. Shared biological children are assigned to the higher earner. Individuals with no children file as single while individuals with children file as head of household.

Figure 1 shows that there is a clear level shift in the average marriage penalty after 2003. The average size of this shift is essentially neutral with respect to marital status and sexual orientation, and there is no substantial time trend in marriage penalties before or after the JGTRRA. For every coresidency type, the fall in the average marriage penalty is on the order of $\$ 900 .{ }^{4}$ Marriage penalties tend to be higher among households

\footnotetext{
${ }^{4}$ I use the term "coresidency type" to differentiate between individuals living together in heterosexual married, heterosexual unmarried, gay male, and lesbian households.
} 


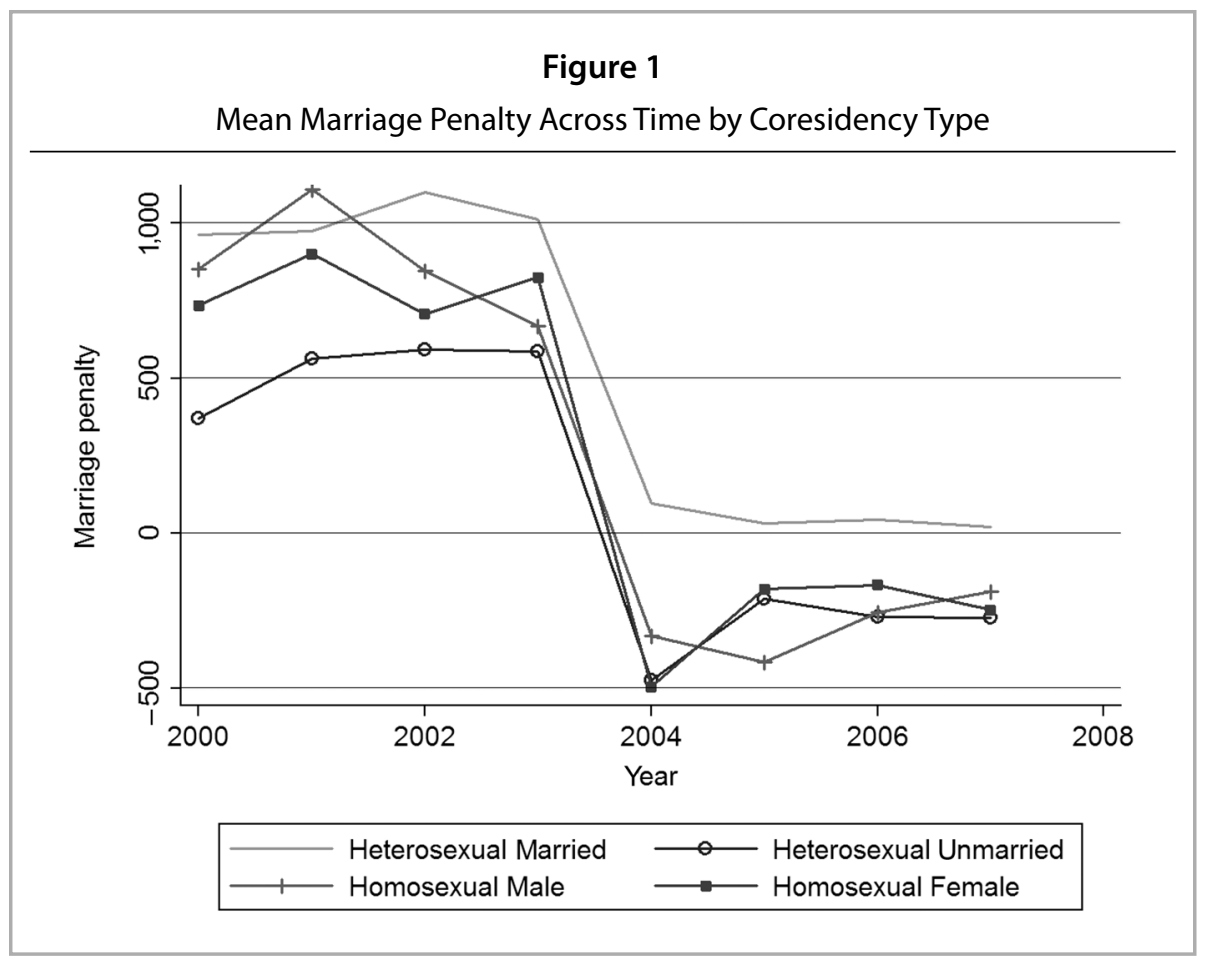

with more children, so that this $\$ 900$ cut pushes the average childless household from the penalty range into the marriage subsidy range, while the average household with children pays a marriage penalty before and after the JGTRRA.

Treating the marriage penalty as a lump-sum payment as in (1) is useful in thinking about the economic incentive to marry. For labor supply choices, we must know how marginal tax rates will change upon marriage. Marginal rates are the same for both earners by definition in married households, while among the unmarried, typically the prime earner's marginal rate is higher than the secondary earner's, since the prime earner typically earns more. Holding constant all other elements of $y_{e}$, the more specialized a household is in terms of labor market earnings, the more the prime earner's tax rate will fall upon marriage and the more the secondary earner's will rise (Eissa and Hoynes, 2000). The effects of marriage on the incentive to work will therefore differ across coresidency and earner type, depending on these factors.

Each worker type in Table 2 experienced a marginal tax rate cut in 2003, ranging from 1.3 percentage points for secondary-earning gay men to 2.3 percentage points for unmarried heterosexual women. Let the "rate marriage penalty" be the increase in marginal tax rates experienced by an individual when they enter into marriage. For every coresidency type, the marginal tax rate for secondary earners rises upon marriage. Homosexual rate marriage penalties are significantly lower than married women's, but 


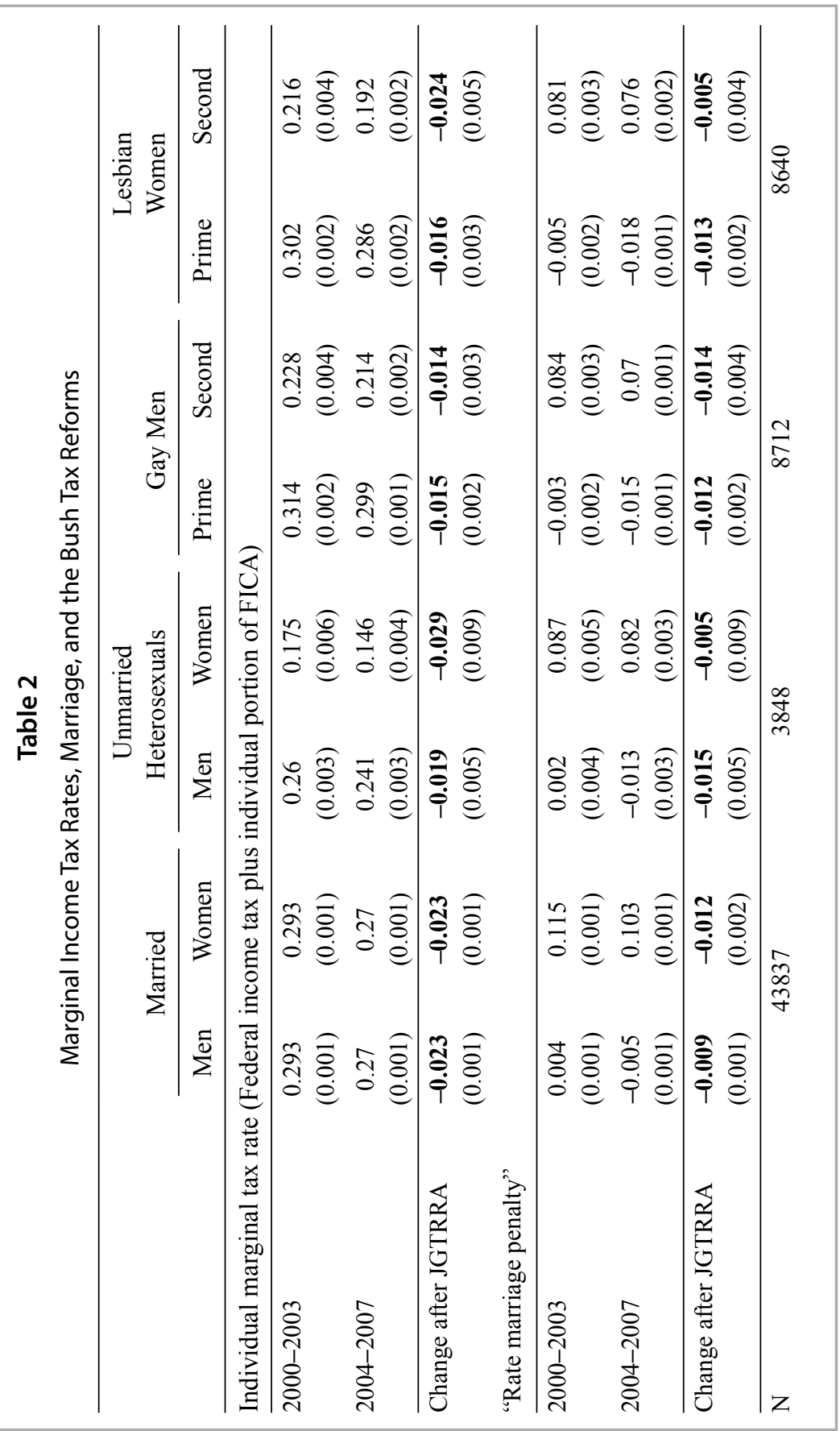


are statistically indistinguishable from heterosexual unmarried couples. Prior to the JGTRRA, heterosexual men's marginal rates tended to rise slightly upon marriage, while the rates of homosexual prime-earners fell. This rate marriage penalty fell in 2004 for all earner types. As shown in section IV.A.1, homosexual secondary earners are more similar to unmarried women than to married women in terms of labor market outcomes.

\section{EMPIRICAL RESULTS}

\section{A. Labor Supply}

There is a very large literature studying the effects of taxation on household labor supply choices. The methodology often takes the form of instrumental variables (IV) estimates (Mroz (1987) surveys the early literature in this vein). ${ }^{5}$ Recent contributions to the literature using instruments similar to those in this study include Devereaux (2004), Blau and Kahn (2007), and Antecol and Steinberger (forthcoming), with this last paper focusing in particular on lesbian households. Orrefice (2011), Leppel (2009), and Tebaldi and Elmslie (2006) all study differences in labor supply choices by sexual orientation, but do not use exogenous net wage variation as a source of identification. A closely related literature uses tax reform to identify responses in taxable earnings to taxation. Singleton (2011) uses the EGTRRA and JGTRRA to estimate these sensitivities, but does not consider sexual orientation.

Estimates of the labor supply function by coresidency type and primary/secondary worker status are presented in section IV.A.1. Section IV.A.2 uses those estimates to introduce an alternative measure of the marriage penalty, the "endogenous" penalty, which estimates taxation as a function of optimal labor market responses to the shift in tax schedule that occurs upon marriage or divorce.

\section{IV Estimates of Own- and Partner-Wage Effects}

Suppose that an individual's labor market hours provided, conditional on working, is given by the equation

$$
h_{i c e t}=\alpha_{c e}^{1} \ln \left(w_{i c e t}^{o}\left(1-\mu_{i c e t}^{o}\right)\right)+\alpha_{c e}^{2} \ln \left(w_{i c e t}^{p}\left(1-\mu_{i c e t}^{p}\right)\right)+\alpha_{c e}^{3} I_{i c t}+\alpha_{c e}^{4} X_{i c e t}+\varepsilon_{i c e t},
$$

where $i$ indexes households across coresidency types $c$, earner types (primary or secondary) $e$, and time periods $t$. Annual hours worked $h$ is a function of (the log of) both the individual's and partner's net wages, market wages $w^{o}$ and $w^{p}$ times one minus their respective marginal rates $\mu . I_{i c t}$ measures the household's non-labor market income, and $X_{\text {icet }}$ is a vector of individual and household characteristics. ${ }^{6}$ Educational attainment is

\footnotetext{
Simple difference-in-differences estimates are also widely used in the literature, as in Eissa (1995), LaLumia (2008), and Crossley and Jeon (2007).

6 In every specification reported, these covariates include year effects, an indicator for whether the family has children, and a continuous variable measuring the number of children. In some specifications, it also includes the inverse Mills ratio and an indicator for the partner's participation in the labor market.
} 
not included since it is used as a grouping instrument, so that the $\alpha^{1}$ coefficient is not interpretable as the compensated labor supply elasticity, but instead as the effect of a lifetime wage increase (Blundell and MaCurdy, 1999). All coefficients are allowed to differ across the eight individual types $c e$.

Many secondary earners choose not work, and I model this choice of labor market participation at the extensive margin in addition to the intensive margin hours choice (Heckman, 1993; Heim, 2007; Kimmel and Kniesner, 1998). This extensive margin choice is important for two reasons. First, it is used to account for selection into the work force when estimating (2). Second, for the fairly large changes in tax rates seen in Table 2, a substantial proportion of secondary earners may opt into or out of the work force when they alter their marital status.

The estimation procedure closely follows that of Heim (2007), which in turn follows Mroz's (1987) selection correction methodology and adds a step to recover extensive margin elasticities. First, participation choice $L_{i c t}$ is modeled as a function of purely demographic characteristics. Time-varying regional characteristics, racial and ethnic background characteristics, and state-level differences in the unemployment rate (all summarized in the vector $Z_{i c}$ ) affect a secondary earner's likelihood of working: $L_{i c t}=\delta_{c}^{1} I_{i c t}+\delta_{c}^{2} Z_{i c t}+\varepsilon_{i c t}$. From this we can calculate the inverse Mills ratio, which is included in the $X_{\text {icet }}$ vector for secondary workers in (2) to account for selection into the workplace.

Since hours worked and wages are clearly endogenously determined, ordinary least squares (OLS) regression of labor market outcomes on net wages will be biased. Two sources of exogenous variation in net-of-taxation marginal wages are used. First, (2) is estimated using data only from 2003 and 2004, exploiting the unexpected break in tax rates, all else equal, caused by the JGTRRA. ${ }^{7}$ Second, exogenous group-membership indicators are used as instruments for wages (Angrist, 1991). The identifying assumption is that the demographic groups are defined such that they are unrelated and unchangeable with respect to the policy change, but the policy change has different effects on the different groups (Blundell, Duncan, and Meghir, 1998).

Because of the progressivity of the tax schedule and programs like the EITC and the Alternative Minimum Tax, the tax cuts will have a different effect on households of different income levels. Each partner's birth year and level of education are taken to be exogenous with respect to current economic conditions. Rates and marriage penalties are fairly sensitive to the presence of children, so groups according to the number of children age $2-15$ in the household are also defined (I exclude older and younger children to avoid the possibilities of endogenous childbirth or exit from the household). Three categories for each of these variables are created. Instruments for both own- and partner-wages are included, to account for the presence of assortative mating (Devereaux, 2004; Antecol and Steinberger, forthcoming). Allowing group means to differ across time generates $54(=3 \times 3 \times 3 \times 2)$ groups per partner type, with two partner labor market choices represented in each regression.

\footnotetext{
In addition, a short time horizon reduces any potential impact of a violation of the "parallel-lines" assumption implicit in the class of instrumental variables estimators that I apply (Blundell, Duncan, and Meghir, 1998).
} 
The first-stage estimates of own- and partner-wages are used to estimate both (2) and the participation choice as a function of changes in the tax code

$$
L_{i c t}=\beta_{c}^{1} \ln \left(\hat{w}_{i c t}^{o}\left(1-\mu_{i c t}^{o}\right)\right)+\beta_{c}^{2} \ln \left(\hat{w}_{i c t}^{p}\left(1-\mu_{i c t}^{p}\right)\right)+\beta_{c}^{3} I_{i c t}+\beta_{c}^{4} Z_{i c t}+\varepsilon_{i c t} .
$$

Since both (2) and (3) include generated regressors, standard errors are generated by bootstrap. The main source of identifying variation for the extensive margin participation choice are geographic and racial/ethnic differences, while the main sources of variation for the hours choice are worker age, education, and the presence of children. Table 3 presents estimates of the labor supply model. Panel a gives the basic grouped-mean IV estimates without correction for selection. Panel $b$ includes both selection corrections and the joint estimate of the full participation equation.

Primary earners are fairly similar across coresidency type. Own-wage coefficients tend to be small or statistically indistinguishable from zero at conventional levels. The heterosexual male coefficients suggest an uncompensated own-wage elasticity between 0.04 and $0.06 .{ }^{8}$ For gay men, the (also statistically insignificant) elasticity estimates range from 0.03 to -0.03 . We can never reject the hypothesis that the sensitivity of hours worked to wages (either their own, or their partner's) between married men and prime-earning homosexuals is equal. Correcting for selection of partners into the labor force reduces our estimates of the sensitivity of prime hours to partner wages in all coresidency types. One important distinction among prime earners is that married men work slightly (and statistically insignificantly) fewer hours when their wife works, but for all other coresidency types, expected annual hours increase by between 129 (for gay men) and 172 (for heterosexual unmarried men) hours when the partner begins to work.

The differences across coresidency type are more substantial among secondary workers. There are essentially two types of secondary earners: married women, and everyone else. Consistent with the literature (Mroz, 1987; Blundell and MaCurdy, 1999), in both panels married women have upward-sloping supply curves. Panel b implies an uncompensated own-wage elasticity among working married women of 0.14 . Secondary-earner homosexuals and unmarried heterosexual women all behave similarly in terms of labor supply. Own- and partner-wage coefficients among these groups are the opposite sign as those of married women. Statistically, we always reject equivalence of wage effects between secondary-earning homosexuals and married women, but we cannot reject equivalence to unmarried women's wage coefficients. Homosexual secondary earners' hours in particular are very sensitive to partner wages. The uncompensated partnerwage elasticities for secondary earners in panel $b$ are 0.23 for gay men and 0.22 for lesbian females. Controlling for labor market selectivity generally increases our estimates of the sensitivity of labor supply to own-wages and partner-wages for secondary earners.

Similarly, married women opt into and out of the market in a way different from secondary earners in the other coresidency groups. The own-wage sensitivity of participation

8 Elasticity estimates are given by $\alpha^{1 /} \bar{h}$, where $\bar{h}$ is evaluated at the $c e$ group mean, conditional on working. 
for married women is substantially larger than for the other groups. The marginal effect of changes in own log wage on employment probability is 0.21 for married women, but only 0.089 for gay men, the next-most sensitive group. The partner-wage effect is negative for married women and positive for all others. With respect to partner wages, lesbian women are almost twice as sensitive as the other nonmarried groups, with a marginal effect of partner log wage of 0.216 , versus 0.12 for gay men and unmarried women.

Antecol and Steinberger (forthcoming) also find negative own-wage elasticities among lesbian women. Stevenson and Wolfers (2007) argue that childless couples are much more likely to form couples on the basis of assortative mating (rather than labor market specialization). Black, Sanders, and Taylor (2007) argue that since homosexual couples have fewer children, they tend to gravitate to higher-private-amenity, higher-cost areas, where the rewards to living in a dual-earner households are greater, encouraging household sorting by ability.

\section{Endogenous Marriage Penalty}

Given estimates of labor supply as a function of net-of-taxes wages, we can return to the measurement of the marriage penalty. Table 2 shows that there are substantial changes in marginal tax rates upon marriage, and so this assumption is rather unappealing. Instead, Table 3 tells us that workers will adjust participation and hours in response to changes in the tax schedule. These adjustments will change the tax burden, and so will affect the marriage penalty. This section describes an alternate way of calculating the marriage penalty, allowing for endogenous hours response to marriage and divorce, and describes the sources of the differences between the measures.

A worker's expected labor income, given the $\hat{\alpha}$ parameters are estimated in the previous section, is $\hat{h}_{i c e t}=\hat{\alpha}_{c e}^{1} \ln \left(w_{\text {icet }}^{o}\left(\mu_{i c e t}^{o}\right)\right)+\hat{\alpha}_{c e}^{2} \ln \left(w_{i c e t}^{p}\left(1-\mu_{i c e t}^{p}\right)\right)+\hat{\alpha}_{c e}^{3} I_{i c t}+\hat{\alpha}_{c e}^{4} X_{\text {icet }}$. A worker's labor supply choice will change as a function of changes in both her own marginal tax rate and her partner's. The marginal tax rate $\mu$ is in turn a function of labor market choices. The endogenous penalty is estimated as follows. First, we predict each worker's participation and hours choice, given married and single tax rates and exogenous household characteristics. If the secondary worker is predicted to opt out of the labor market, their labor market income is set to zero. The predicted hours of both partners are then used to predict new married and single tax liabilities (calculated again by TAXSIM), holding constant labor market choices. This in turn implies another set of hours and participation choices, and so on. This process is iterated until average tax rates for both household members converge, generating predicted tax liabilities and rates when single and when married.

Denote the endogenous predictions of hours under each tax system of each earner $e \in$ $(1,2)$ to be $\hat{h}_{q}^{s}$, where $q \in(m, s)$ indicates marital status (and $-q$ implies the counterfactual marital status). This hours choice implies a predicted average tax rate $\hat{\tau}_{q}^{s}$. The endogenous penalty can be stated as $E=\hat{\tau}_{m}\left(w^{1} \hat{h}_{m}^{1}+w^{2} \hat{h}_{m}^{2}+I\right)-\left(\hat{\tau}_{s}^{1}\left(w^{1} \hat{h}_{s}^{1}+I / 2\right)+\hat{\tau}_{s}^{2}\left(w^{2} \hat{h}_{s}^{2}+I / 2\right)\right)$, where $I$ measures household non-work income. The instantaneous penalty $P$ is defined 


\begin{tabular}{|c|c|c|c|c|c|c|c|c|c|c|c|c|c|}
\hline 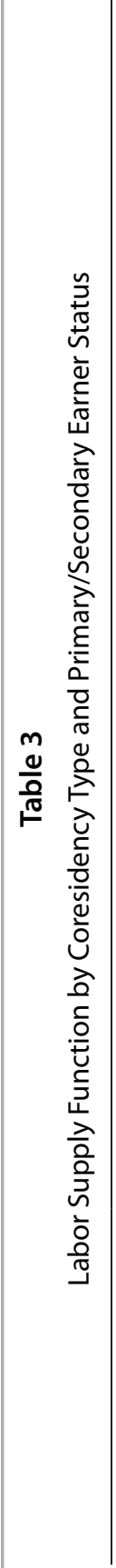 & 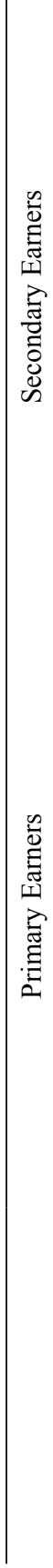 & 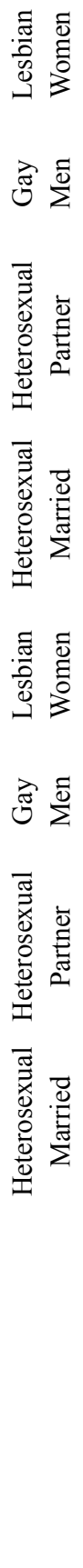 & 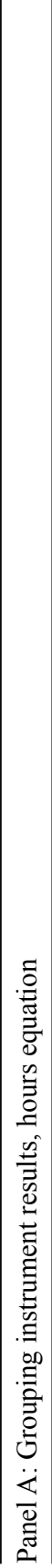 & 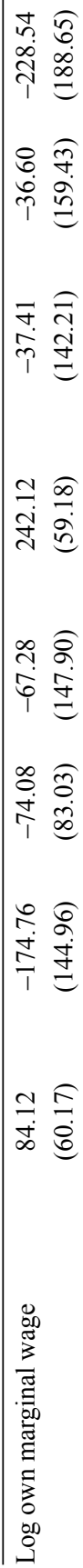 & 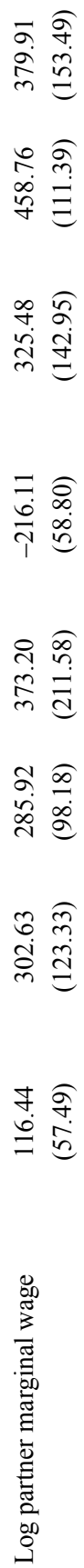 & 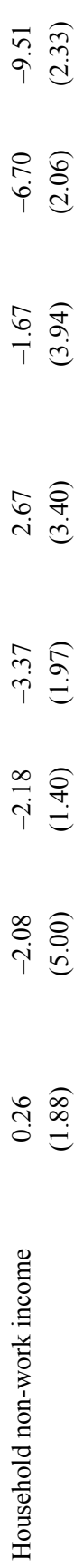 & 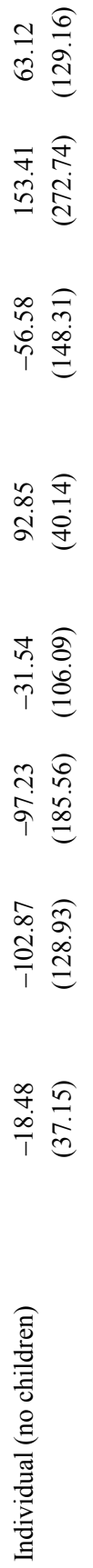 & 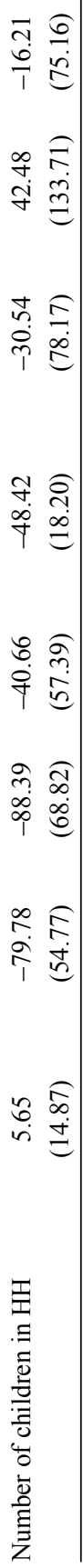 & 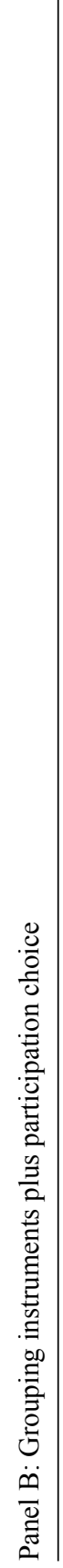 & (2) & 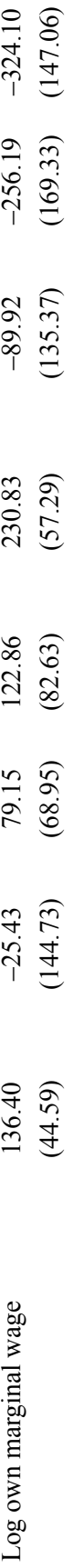 & 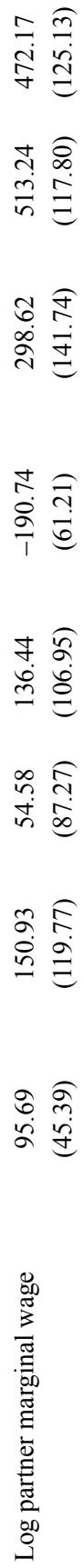 & 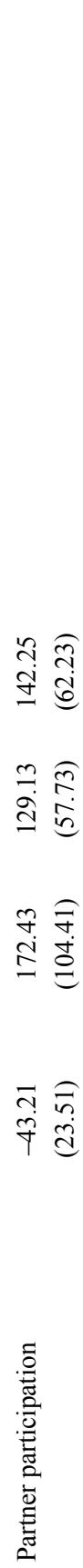 \\
\hline
\end{tabular}




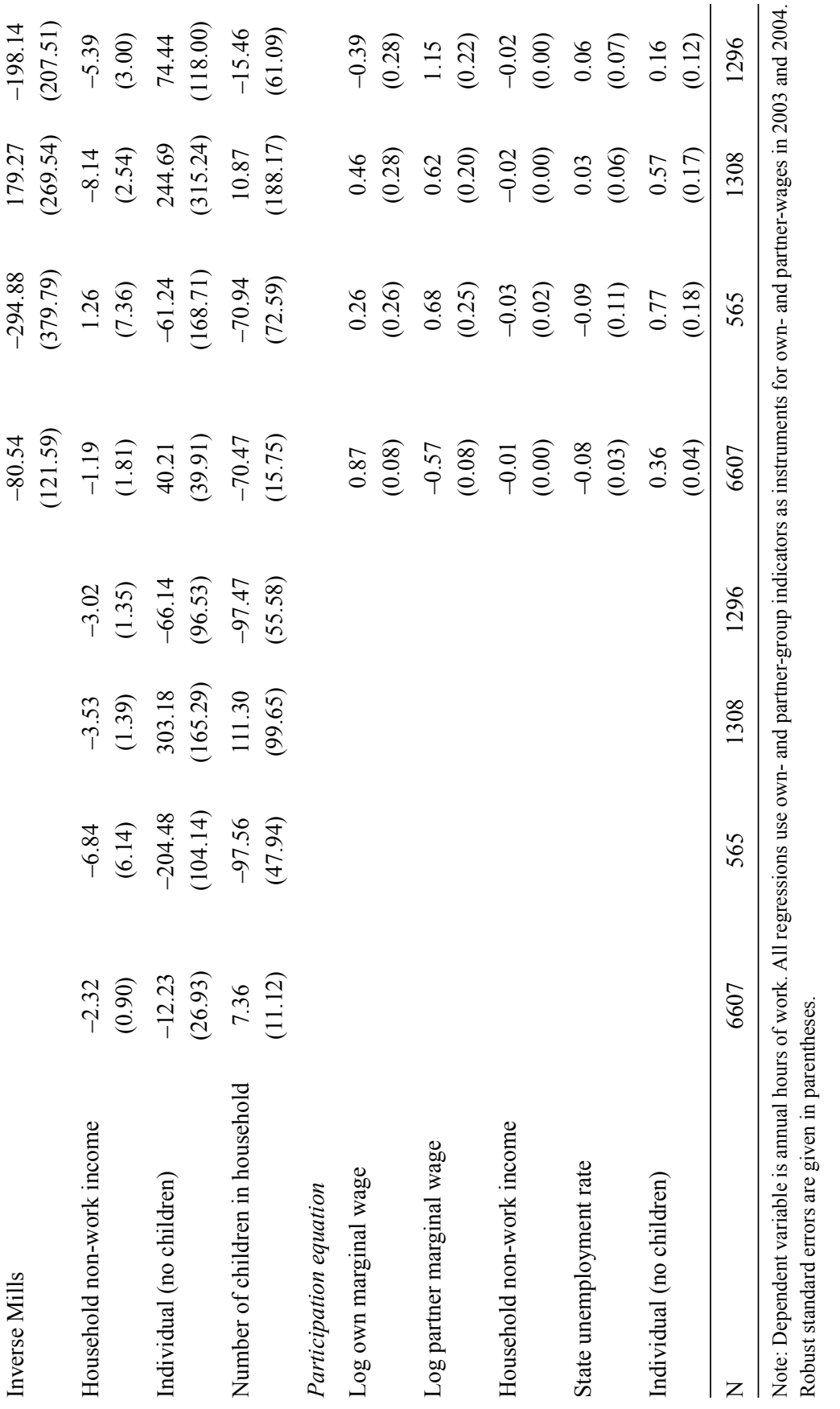


analogously by omitting the hats. I show in an online appendix that the bias (overstatement) of $P$ relative to $E$ is

$$
\begin{aligned}
& P-E=\sum_{e=1,2} w^{e}\left[h^{e}\left(\left(\tau_{m}-\tau_{s}^{e}\right)-\left(\hat{\tau}_{m}-\hat{\tau}_{s}\right)\right)+\left(h^{e}-\hat{h}_{q}^{e}\right)\left(\hat{\tau}_{m}-\hat{\tau}_{s}^{e}\right)\right. \\
& \left.+\hat{\tau}_{-q}^{e}\left(\left(h^{e}-h^{e}\right)-\left(\hat{h}_{m}^{e}-\hat{h}_{s}^{e}\right)\right)+\left(\tau_{-q}^{e}-\hat{\tau}_{-q}^{e}\right)\left(\hat{h}_{m}^{e}-\hat{h}_{s}^{e}\right)\right] \\
& +I\left[\left(\tau_{m}-\hat{\tau}_{m}\right)+\frac{\left(\tau_{s}^{1}-\hat{\tau}_{s}^{1}\right)+\left(\tau_{s}^{2}-\hat{\tau}_{s}^{2}\right)}{2}\right] .
\end{aligned}
$$

There are five main terms in (4). The first term, $w^{e} h^{e}\left(\left(\tau_{m}-\tau_{s}^{e}\right)-\left(\hat{\tau}_{m}-\hat{\tau}_{s}^{e}\right)\right)$, describes the tax rate bias of the instantaneous method: the tax revenue impact of the fact that, because it does not allow workers to adjust labor market choices, the change in the tax rate upon marriage is overstated (evaluated at the observed level of hours worked). The second term, $w^{e}\left(h^{e}-\hat{h}_{q}^{e}\right)\left(\hat{\tau}_{m}-\hat{\tau}_{s}^{e}\right)$, describes the modeling bias: the difference in collected tax revenue due to the difference in predicted labor market earnings in the observed marital state. This does not primarily come from prediction error in the hours equation, which is mean-zero (with one important exception, discussed below). Instead, it comes mostly from the induced correlation between hours and wages that arises when we predict hours according to (2). The third term, $w^{e} \hat{\tau}_{-q}^{e}\left[\left(h^{e}-h^{e}\right)-\left(\hat{h}_{m}^{e}-\hat{h}_{s}^{e}\right)\right]$, describes the instantaneous hours bias: the value of the expected hours response to the changes in taxation upon marriage. Since the subterm $\left(h^{e}-h^{e}\right)$ cancels out by construction, this term measures the impact, all else equal, of hours responses to changes in the tax schedule. The fourth term, $w^{e}\left(\tau_{-q}^{e}-\hat{\tau}_{-q}^{s}\right)\left(\hat{h}_{m}^{e}-\hat{h}_{s}^{e}\right)$, is the counterfactual bias, the difference in the tax value (instantaneous or endogenous) of the predicted hours response calculated in the non-observed marital status. The last term, multiplied by household non-labor income $I$ is the non-work bias, which represents the difference in tax treatment of nonwork income between the two methods. Table 4 decomposes the average difference in the two marriage penalty measures, by coresidency type, into these five sources of bias.

The most striking result of Table 4 is that the average gap between the instantaneous and endogenous measures is essentially zero for heterosexual couples, but negative and quite substantial for homosexual households, amounting to $-\$ 333$ and $-\$ 439$ for homosexual men and women, respectively. This turns the average expected penalty from negative to positive for homosexual couples: the average post-JGTRRA endogenous penalties are $\$ 68$ for gay men and $\$ 131$ for lesbian women. As a practical matter, the instantaneous and endogenous penalties for heterosexual households are quite similar. But the assortative nature of coupling among homosexual workers implies that the marriage penalty tends to be larger among homosexual households once we allow for rational labor market responses to tax incentives. Clearly, accounting for the responsiveness of labor supply to changes in the tax structure could have a large impact on our estimates of the tax revenue changes generated by same-sex marriage legalization. 


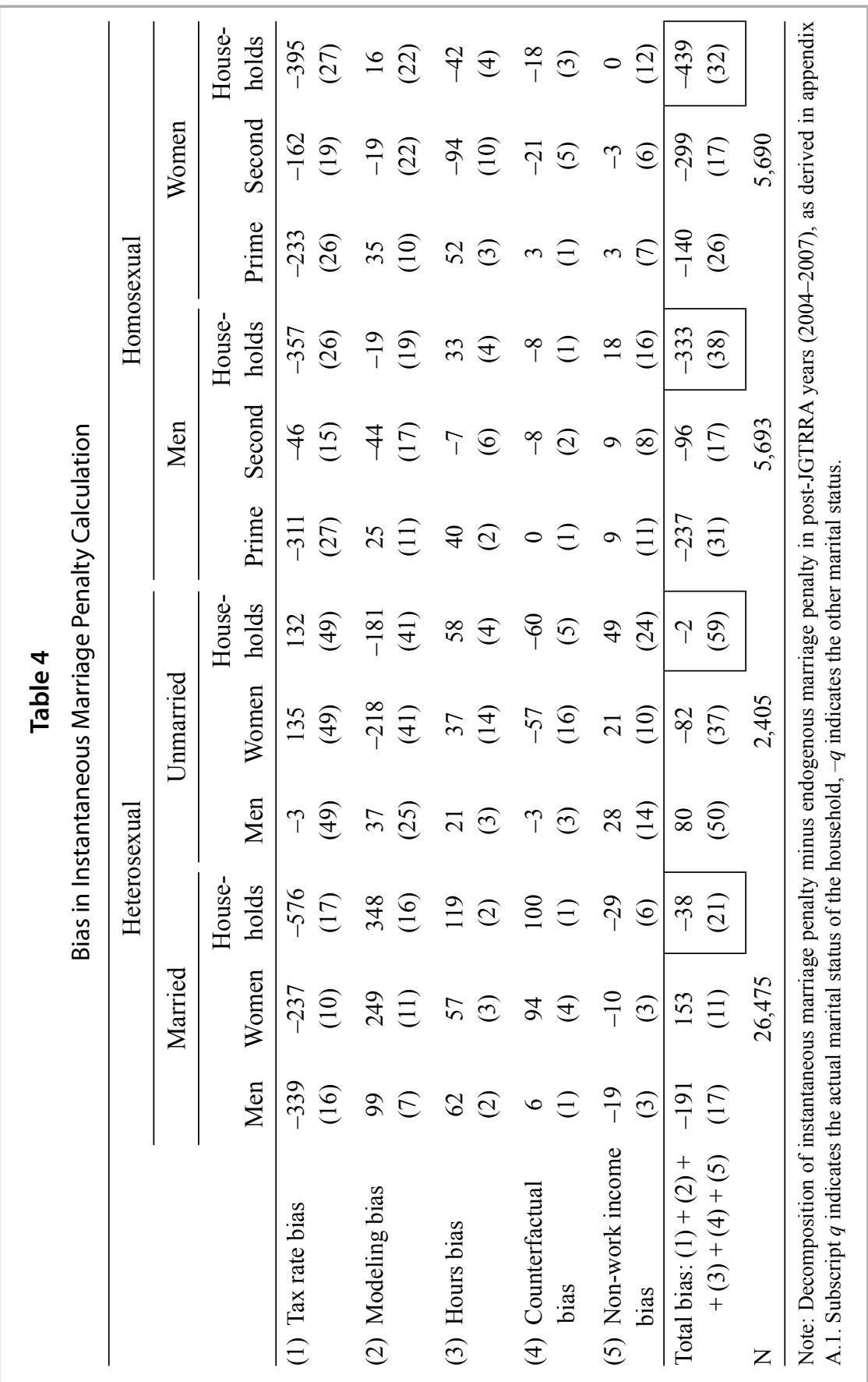


The two biases of primary theoretical interest are the tax rate bias and the hours bias. For both homosexual household types, the vast majority of the instantaneous bias comes from the tax rate bias. Both household members will pay relatively a higher tax rate when married than predicted by the instantaneous method, since $\left(\hat{\tau}_{m}-\tau_{m}\right)>\left(\hat{\tau}_{s}-\tau_{s}\right)$. For prime earner gay men, the instantaneous method indicates that the average tax rate would fall 1.9 percentage points upon marriage, but the endogenous method estimates that it will fall by 1.8 points. Among secondary-earning gay men, the instantaneous method implies that the average rate will increase by 4.3 percentage points upon marriage, while the endogenous method indicates that it will increase by 4.6 percentage points. An important explanatory factor is that endogenous labor market choices imply that the likelihood of unemployment among secondary-earner gay men will be a half a percentage point lower when married than when single, and 1.7 percentage points lower among secondary-earner lesbian females.

While modeling bias is not a major issue for homosexual households, it is substantial among heterosexual women (illustrating one aspect of why the labor supply behavior of secondary earners is of such perennial research interest (Blundell and MaCurdy, 1999)). We tend to over-predict hours for high-wage workers and under-predict hours for low-wage workers for married women. While married women's endogenous participation is almost identical to instantaneous participation (77.7 percent versus 78.3 percent), average endogenous labor market income is predicted to be almost $\$ 3,000$ higher than what is observed.

\section{B. Marriage Choice}

I am aware of no other papers that have studied the consequences of the Bush tax cuts in terms of the marriage market, or that account for the fact that assignment to treatment groups (i.e., the size of the marriage penalty) is non-random with respect to observable characteristics. Alm and Whittington (2003) undertake the most thorough longitudinal study of the effects of taxation on marriage (among heterosexuals). They show that while transitions from non-cohabitation to cohabitation (either married or not) are insensitive to taxation, the transition from unmarried cohabitation to marriage is significantly influenced by changes in the household's instantaneous marriage penalty. Fisher (2011) uses state-level variation in income tax codes and the EITC as an instrument for the marriage penalty, and finds effects that are substantially larger than those estimated by Alm and Whittington (2003). and Badgett, Gates, and Maisel (2008) find little sensitivity of cohabitation status to economic factors among homosexual couples.

The marriage penalty is not distributed randomly with respect to marital status, so simple OLS will provide a biased estimate of the effect of taxes on marriage. Since marital choice is partly a function of the expected marriage penalty, we must estimate marital choice as a function of unexpected changes in the marriage penalty. Alm and Whittington (2003) use variation used from changes in tax law between 1983-1997 to reach their conclusions. They show in previous work (Alm and Whittington, 1996), however, that no discrete changes in the marriage penalty occurred over that time period. 
The JGTRRA was largely unexpected and created the first major decrease in the marriage penalty since 1977 (see Figure 1 of Alm and Whittington (1996)).

The Hirano-Imbens (2005) estimator of the effects of a continuous treatment variable is applied to the heterosexual couples in my sample. The treatment is the "increase" between the expected marriage penalty as a function of the pre-JGTRRA tax schedule $\hat{p}\left(y_{1}, y_{2}\right)$ and the actually-experienced marriage penalty after implementation of the JGTRRA, $p\left(y_{1}, y_{2}\right)$ (or simply $P_{i c t}$ in (5) below). In essence, the expectation $\hat{p}\left(y_{1}, y_{2}\right)$ can be treated as a taxation propensity score. The responsiveness of marital choice to taxation is identified by comparing households with identical $\hat{p}\left(y_{1}, y_{2}\right)$ that are exposed to varying levels of the treatment, $p\left(y_{1}, y_{2}\right)$. To ensure that the necessary condition of sample overlap is satisfied (Imbens 2004), the data are balanced following Barsky, et al. (2002). The weights constructed by this procedure impose the counterfactual assumption that the distribution of $p\left(y_{1}, y_{2}\right)$ among married household matches the distribution observed among unmarried households. Intuitively, this process places greater weight on the married households that are observably most similar to non-married households in terms of the treatment received. A full description of the methodology may be found in an online appendix.

Under the maintained assumption that this procedure ensures sample balance and random assignment to the marriage penalty conditional on observed characteristics (Imbens, 2004), we can recover the causal effect of the marriage penalty $P_{i c t}$ on marital choice. Let $M\left(P_{i c t}\right)$ be an indicator function taking a value of one when a coresident couple is married, and zero otherwise. By estimating the probit equation

$$
\begin{aligned}
& E\left(M\left(P_{i c t}\right)\right)=\alpha_{0}+\alpha_{1} P_{i c t}+\alpha_{2} P_{i c t}^{2}+\alpha_{3} \hat{p}\left(y_{1}, y_{2}\right)+\alpha_{4} \hat{p}\left(y_{1}, y_{2}\right)^{2} \\
& +\alpha_{5} P_{i c t} \cdot \hat{p}\left(y_{1}, y_{2}\right)+\varepsilon_{i c t},
\end{aligned}
$$

we recover $E\left(M\left(P_{i c t}\right)\right)$, the "dose-response" or "average potential outcome" function.

Figure 2 plots the estimated marriage likelihood as a function of the marriage penalty, for three types of heterosexual households: those with no children, those with one child, and those with more than one child. The plots are estimated via local polynomial regression. The black curves are estimates based on the instantaneous penalty, while grey curves are estimates based on the endogenous penalty (with bootstrapped 95 percent confidence intervals in dashed grey lines).

There are three main conclusions from Figure 2. First, the marriage penalty conveys a clear negative treatment effect among childless couples. Imposing the assumption of strict linearity in the treatment effect, the coefficient from regressing predicted marriage outcomes (from (5)) on the instantaneous marriage penalty is -0.000016 . Evaluated at a typical marriage penalty reduction of around $-\$ 900$, this implies an increase in the probability of marriage of 0.3 percentage point for a childless couple (from 85.0 to 85.3 percent). This effect is statistically significant, and in line with the previous literature, if somewhat smaller than that of Alm and Whittington (2003).

Second, the results are insensitive to whether we use the instantaneous or endogenous measure of the marriage penalty. Among childless couples, the linear treatment effect 


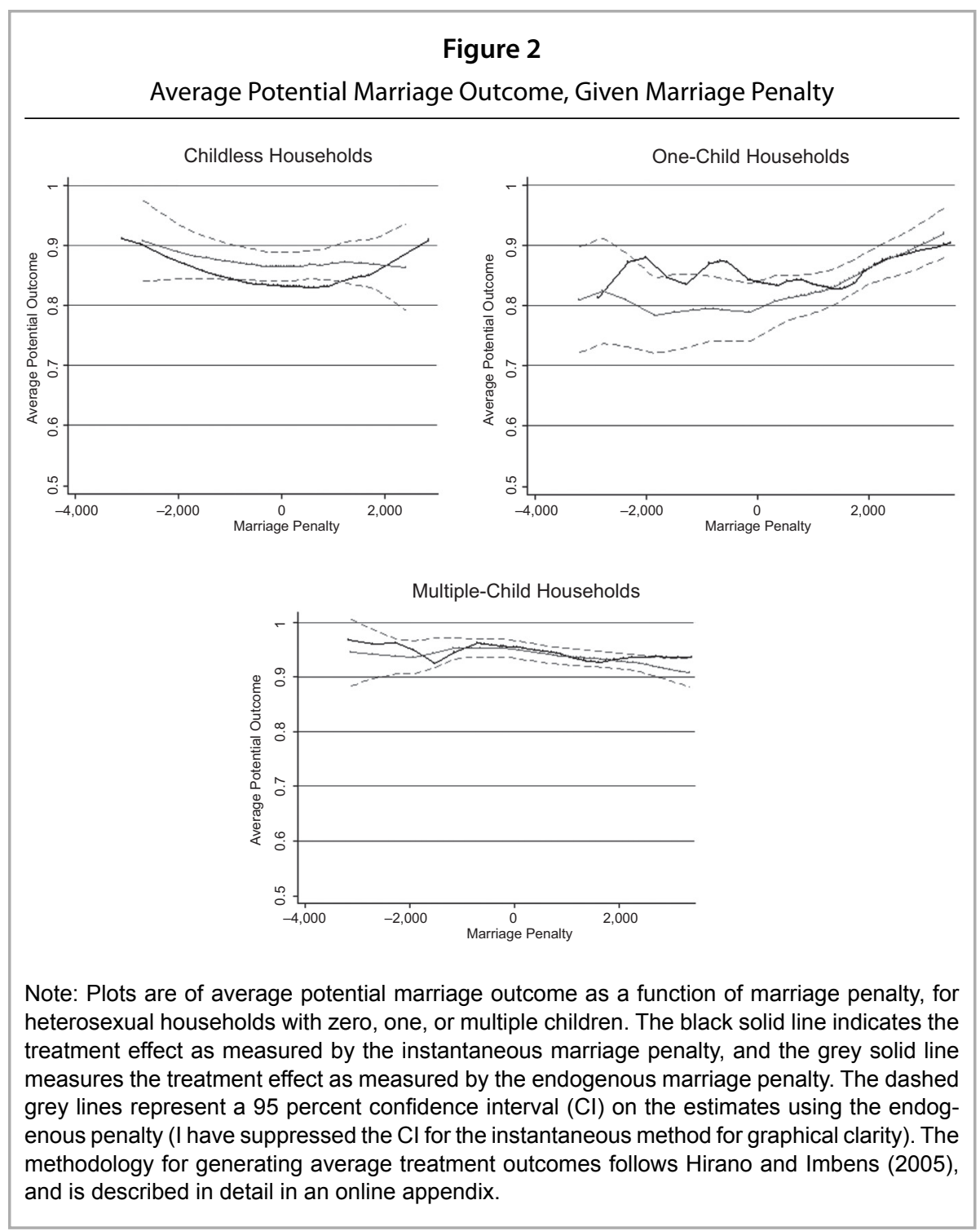

of the endogenous marriage penalty on marriage likelihood is -0.000013 . This at once confirms that past studies of the relationship between taxation and marriage are robust to this new measure of the marriage penalty, while allowing us to apply more economically realistic measures of the tax revenue response to changes in marital status.

Third, among households with children, there is little evidence that unexpected changes in the marriage penalty cause changes in marriage likelihood. Both marriage penalty measures suggest an insignificant negative relationship between marriage and penalties among multi-child households. The instantaneous penalty among single-child 
households shows an essentially flat relationship to marriage likelihood, and there is only a weak and insignificant relationship using the endogenous penalty. The conservative conclusion is to reject the hypothesis of a consistent treatment effect, positive or negative, in this group.

\section{CONSEQUENCES OF SAME-SEX MARRIAGE LEGALIZATION}

A primary difficulty in estimating the effect of same-sex marriage legalization on federal income tax collection is knowing the marriage rate applicable to homosexual couples. Previous studies have applied a number of rates. Badgett and Sears (2005) and Badgett (2010) assume a 50 percent same-sex marriage rate; ${ }^{9}$ the latter also cites a number of studies which suggest that 80 percent of young gay individuals hope to marry. The Congressional Budget Office (CBO, 2004) assumes that to a first approximation, all cohabiting same-sex couples would marry.

There are alternatives to these assumptions. One might assume that marriage likelihood is a function of demographic characteristics and is unrelated to sexual orientation. This assumption is imposed by estimating the likelihood of marriage (among heterosexuals) via probit regression, as a function of age, terminal education, number of children in the household, and state of residence. Alternatively, one could assume that marriage likelihood among same-sex couples is responsive to the marriage penalty in exactly the same way as it is among heterosexuals: the dose-response functions of Figure 2 apply to same-sex couples. The average marriage likelihood among childless couples is 85 percent. While this is much higher than the preferred value of Badgett and Sears (2005) and Badgett (2010), it is less than that used by the CBO, and is in line with survey data on expressed willingness-to-marry among same-sex couples (Badgett, 2010).

In addition, to identify households that were clearly same-sex, it was necessary to drop households with allocated marital status. Black, et al. (2007) estimate that 9.6 percent of women so dropped were actually same-sex couples, and 17.1 percent of the men were actually same-sex. Assuming that being dropped is unrelated to characteristics that determine labor market choices, we can re-weight observed households to represent the full population of coresident same-sex households (recalling the important caveat that not all households that might marry are observed as coresident in the Census, so that these estimates are certainly conservative in terms of the number of households).

Let $m_{i}$ be the probability of marriage, and $T_{i}^{q}$ be the tax liability of household $i$ given marital status $q$. Given that all same-sex couples are single prior to legalization, the expected change in federal tax liability after legalization is $m_{i}\left(T_{i}^{m}-T_{i}^{s}\right)$, or $m$ times the marriage penalty. I aggregate to the national level by multiplying this number times its household sampling weight and summing by year. Table 5 presents annual averages for the indicated time frames (2000-2002 and 2005-2007) for the instantaneous penalty and endogenous penalty.

\footnotetext{
9 The Williams Institute has released a series of state-level evaluations of the fiscal impact of state-level same-sex marriage legalization, which may be found at http://www2.law.ucla.edu/williamsinstitute// publications/Policy-Econ-index.html.
} 


\section{Table 5}

Changes in Federal Income Tax Revenue After Same-Sex Marriage Legalization

\begin{tabular}{lcc}
\hline & Instantaneous Penalty & Endogenous Penalty \\
\hline Pre-JGTRRA (2000-2002) & & \\
\hline $\mathrm{m}=0.5$ & 97 & 118 \\
& $(8)$ & $(8)$ \\
$\mathrm{m}=1$ & 202 & 231 \\
& $(11)$ & $(11)$ \\
$\mathrm{m}=\mathrm{f}$ (demographics) & 183 & 208 \\
& $(10)$ & $(10)$ \\
$\mathrm{m}=$ heterosexual conditional & 179 & 200 \\
$\quad$ marriage expectation & $(10)$ & $(10)$ \\
$\mathrm{m}=$ conditional marriage & 197 & 228 \\
expectation, re-weighted & $(11)$ & $(11)$
\end{tabular}

Post-JGTRRA (2005-2007)

\begin{tabular}{lcc}
\hline $\mathrm{m}=0.5$ & -38 & 19 \\
$\mathrm{~m}=1$ & $(6)$ & $(5)$ \\
& -81 & 34 \\
$\mathrm{~m}=\mathrm{f}$ (demographics) & $(9)$ & $(8)$ \\
& -55 & 39 \\
$\mathrm{~m}=$ heterosexual conditional & $(8)$ & $(7)$ \\
$\quad$ marriage expectation & -68 & 27 \\
$\mathrm{~m}=$ conditional marriage & $(8)$ & $(7)$ \\
$\quad$ expectation, re-weighted & -78 & 34 \\
\hline
\end{tabular}

Note: Units are millions of 2004 dollars. Standard errors are given in parentheses, generated by taking random draws from $\mathrm{U}[0,1]$ to determine who marries, summing the change in annual tax payment, and bootstrapping 1000 repetitions over this measure.

Income tax revenue estimates from 2000-2002 are presented mainly to compare the post-JGTRRA estimates to the results of previous work. Congressional Budget Office (2004) estimated a pre-JGTRRA increase in income tax revenue between \$200 million to $\$ 400$ million, given a 100 percent marriage rate and the instantaneous penalty measure. My estimate in this case is a $\$ 202$ million revenue increase, at the bottom of the CBO range. Between 2000-2002, the endogenous method of measuring the marriage penalty implies revenue increases that are consistently above those of the instantaneous 
method. At the high end of the estimates, applying the endogenous penalty and assuming a 100 percent marriage rate among observed same-sex couples, the federal revenue gain is $\$ 231$ million. At the low end, assuming a 50 percent mean marriage rate and applying the instantaneous penalty, the revenue gain to marriage legalization would have been $\$ 97$ million.

My preferred results are the estimates based on the endogenous marriage penalty, using the heterosexual conditional marriage expectation, and re-weighting to adjust for same-sex couples inadvertently dropped from the sample. This measure allows for optimizing agents to respond to the tax system in terms of both marriage and labor supply choice. Under this set of assumptions, the estimated income tax revenue increase is $\$ 34$ million (and no larger than $\$ 39$ million, for any plausible set of assumptions). In the time period between the JGTRRA and the economic crisis of 2008, the instantaneous method understates the revenue gains from legalization, relative to the endogenous penalty, by $\$ 57$ million to $\$ 115$ million annually.

In the context of the federal budget, where income tax revenues are on the order of $\$ 1$ trillion, these revenue gains are obviously very small. Further, they do not incorporate other changes in federal government expenditure that would arise from same-sex marriage legalization. These changes are projected to generate a gain of $\$ 300$ million in the federal budget annually, coming from additional employee benefit costs and savings on federal supplemental support programs (Congressional Budget Office 2004, 2009). While the Table 5 estimates substantially reduce the overall projected budget windfall, they do not make the windfall negative. The estimates that fully encompass economic incentives put the overall gain in the neighborhood of $\$ 430$ million, and even the most pessimistic set of assumptions (100 percent marriage rate with an instantaneous penalty) imply an overall windfall of $\$ 320$ million.

\section{CONCLUSION}

This paper exploits a major exogenous break in the tax code to estimate the labor market response to changes in the tax rate that would accompany same-sex marriage, were it legalized. The same tax code shock allows us to present new evidence on the sensitivity of marriage to taxes among cohabiting couples.

Primary and secondary earners in homosexual households make very different labor market choices as a function of net wages. Further, the supply functions of homosexual couples are very different from heterosexual married couples. As such, it is reasonable to assume that homosexual and heterosexual couples' tax burdens might differ after marriage, all else equal. A novel measure, the endogenous marriage penalty, measures the change in tax burden upon marriage as a function of the optimal labor market choices of both partners across households of different types. The most reasonable estimates of the changes in tax revenue upon legalization are in the $\$ 20$ million to $\$ 40$ million range, somewhat lower than government revenue projections, but large enough to result in net budget effects that are clearly positive. 


\section{REFERENCES}

Alm, James, M. V. Lee Badgett, and Leslie A. Whittington, 2000. "Wedding Bell Blues: The Income Tax Consequences of Legalizing Same-Sex Marriage." National Tax Journal 53 (2), 201-214.

Alm, James, and Leslie A. Whittington, 1996. "The Rise and Fall and Rise... of the Marriage Tax." National Tax Journal 49 (4), 571-589.

Alm, James, and Leslie A. Whittington, 2003. "Shacking Up or Shelling Out: Income Taxes, Marriage, and Cohabitation." Review of Economics of the Household 1 (3), 169-186.

Angrist, Joshua D., 1991. "Grouped-data Estimation and Testing in Simple Labor-Supply Models." Journal of Econometrics 47 (2-3), 243-266.

Antecol, Heather, and Michael D. Steinberger, forthcoming. "Labor Supply Differences between Married Heterosexual Women and Partnered Lesbians: A Semi-Parametric Decomposition Approach.” Economic Inquiry.

Auten, Gerald, Robert Carroll, and Geoffrey Gee, 2008. "The 2001 and 2003 Tax Rate Reductions: An Overview and Estimate of the Taxable Income Response." National Tax Journal 61 (3), 345-364.

Badgett, M. V. Lee, 2010. "The Economic Value of Marriage for Same-Sex Couples." Drake Law Review 58 (4), 1081-1116.

Badgett, M. V. Lee, Gary J. Gates, and Natalya C. Maisel, 2008. "Registered Domestic Partnerships Among Gay Men and Lesbians: The Role of Economic Factors." Review of Economics of the Household 6 (4), 327-346.

Badgett, M. V. Lee, and R. Bradley Sears, 2005. "Putting a Price on Equality? The Impact of Same-Sex Marriage on California's Budget." Stanford Law and Policy Review 16 (1), 1-36.

Barsky, Robert, John Bound, Kerwin Kofi Charles, and Joseph P. Lupton, 2002. "Accounting for the Black-White Wealth Gap: A Nonparametric Approach.” Journal of the American Statistical Association 97 (459), 663-673.

Berliant, Marcus, and Paul Rothstein, 2003. "Possibility, Impossibility, and History in the Origins of the Marriage Tax." National Tax Journal 56 (2), 303-317.

Black, Dan A., Gary Gates, Seth G. Sanders, and Lowell J. Taylor, 2007. "The Measurement of Same-Sex Unmarried Partner Couples in the 2000 U.S. Census." California Center for Population Research On-Line Working Paper Series CCPR-023-07. University of California, Los Angeles, CA.

Black, Dan A., Seth G. Sanders, and Lowell J. Taylor, 2007. "Economics of Lesbian and Gay Families." Journal of Economic Perspectives 21 (2), 53-70.

Blau, Francine D., and Lawrence M. Kahn, 2007. "Changes in the Labor Supply Behavior of Married Women: 1980-2000.” Journal of Labor Economics 25 (3), 393-438. 
Blundell, Richard, Alan Duncan, and Costas Meghir, 1998. "Estimating Labor Supply Responses using Tax Reforms." Econometrica 66 (4), 827-862.

Blundell, Richard, and Thomas MaCurdy, 1999. "Labor Supply: A Review of Alternative Approaches." In Ashenfelter, Orley, and David Card (eds.), Handbook of Labor Economics, Volume 3, 1560-1695. Institute for Fiscal Studies, London, UK.

Congressional Budget Office, 2004. The Potential Budgetary Impact of Recognizing Same-Sex Marriages. Congressional Budget Office, Washington, DC.

Congressional Budget Office, 2009. H.R. 2517, Domestic Partnership Benefits and Obligations Act of 2009. Congressional Budget Office, Washington, DC.

Crossley, Thomas F., and Sung-Hee Jeon, 2007. "Joint Taxation and the Labour Supply of Married Women: Evidence from the Canadian Tax Reform of 1988." Fiscal Studies 28 (3), $343-365$.

Devereaux, Paul J., 2004. "Changes in Relative Wages and Family Labor Supply." Journal of Human Resources 39 (3), 696-722.

Eissa, Nada, 1995. "Taxation and Labor Supply of Married Women: The Tax Reform Act of 1986 as a Natural Experiment.” NBER Working Paper No. 5023. National Bureau of Economic Research, Cambridge, MA.

Eissa, Nadia, and Hilary Williamson Hoynes, 2000. "Explaining the Fall and Rise in the Tax Cost of Marriage: The Effects of Tax Laws and Demographic Trends, 1984-97." National Tax Journal 53 (3), 683-711.

Feenberg, Daniel Richard, and Elizabeth Coutts, 1993. "An Introduction to the TAXISM Model," Journal of Policy Analysis and Management 12 (1), 189-194.

Fisher, Hayley, 2011. "Marriage Penalties, Marriage, and Cohabitation.” Working Paper No. 2011-12. University of Sydney, New South Wales, Australia.

Hawkins, Jennifer N., 2009. "Tenth Annual Review of Gender and Sexuality Law, Family Law Chapter: Legal Recognition of Same-Sex Relationships." The Georgetown Journal of Gender and the Law 10 (2), 751-800.

Heckman, James, 1993. "What Has Been Learned About Labor Supply in the Past Twenty Years?" American Economic Review 83 (2), 116-121.

Heim, Bradley T., 2007. "The Incredible Shrinking Elasticities: Married Female Labor Supply, 1978-2002.” Journal of Human Resources 42 (4), 881-918.

Heim, Bradley T., 2009. "Structural Estimation of Family Labor Supply with Taxes." Journal of Human Resources 44 (2), 350-385

Hirano, Keisuke, and Guido W. Imbens, 2005. "The Propensity Score with Continuous Treatments." In Gelman, Andrew, and Xiao-Li Meng (eds.), Applied Bayesian Modeling and Causal Inference from Incomplete-Data Perspectives, 73-84. John Wiley and Sons, Chichester, UK. 
Imbens, Guido W., 2004. "Nonparametric Estimation of Average Treatment Effects under Exogeneity: A Review." The Review of Economics and Statistics 86 (1), 4-29.

Keifer, Donald, Robert Carroll, Janet Holtzblatt, Allen Lerman, Janet McCubbin, David Richardson, and Jerry Tempalski, 2002. "The Economic Growth and Tax Relief Act of 2001: Overview and Assessment of Effects on Taxpayers.” National Tax Journal 55 (1), 89-117.

Kimmel, Jean, and Thomas J. Kneisner, 1998. "New Evidence on Labor Supply: Employment Versus Hours Elasticities by Sex and Marital Status." Journal of Monetary Economics 42 (2), 289-301.

LaLumia, Sara, 2008. "The Effects of Joint Taxation of Married Couples on Labor Supply and Non-wage Income.” Journal of Public Economics 92 (7), 1698-1719.

Leppel, Karen, 2009. "Labour Force Status and Sexual Orientation.” Economica 76 (301), 197-207.

Mroz, Thomas A., 1987. "The Sensitivity of an Empirical Model of Married Women's Hours of Work to Economic and Statistical Assumptions." Econometrica 55 (4), 765-799.

Orrefice, Sonia, 2011. 'Sexual Orientation and Household Decision Making. Same-sex Couples' Balance of Power and Labor Supply Choices.” Labour Economics 18 (2), 145-158.

Savage, Charlie, and Sheryl G. Stolberg, 2011. "Obama Orders End to Defense of Gay Marriage Law.” New York Times, February 23, http://www.nytimes.com/2011/02/24/us/24marriage.html.

Singleton, Perry, 2011. "The Effect of Taxes on Taxable Earnings: Evidence from the 2001 and Related U.S. Federal Tax Acts.” National Tax Journal 64 (2), 323-351.

Sjoquist, David L., and Mary Beth Walker, 1995. "The Marriage Tax and the Rate and Timing of Marriage." National Tax Journal 48 (4), 547-558.

Stevenson, Betsey, and Justin Wolfers, 2007. "Marriage and Divorce: Changes and their Driving Forces.” Journal of Economic Perspectives 21 (2), 27-52.

Tebaldi, Edinaldo, and Bruce Elmslie, 2006. "Sexual Orientation and Labour Supply." Applied Economics 38 (5), 549-562. 